\title{
Pendidikan Pemilih Sebagai Sumber Pembelajaran Pendidikan Kewarganegaraan Untuk Meningkatkan Partisipasi Politik Peserta Didik.
}

\author{
Hariyanti \\ Dept Pendidikan Kewarganegaraan Sekolah Pascasarjana Universitas Pendidikan Indonesia \\ Yantihariyanti25@gmail.com
}

\begin{abstract}
Abstrak
Artikel ini bertujuan mendeskripsikan pendidikan pemilih sebagai sumber pembelajaran pendidikan kewarganegaraan $(\mathrm{Pkn})$ untuk meningkatkan partisipasi politik peserta didik. metode yang digunakan adalah kajian literature melalui elaborasi sumber yang sesuai dengan tema kepenulisan baik dari rujukan buku maupun jurnal penelitian. Partisipasi politik merupakan keniscayaan dalam negara demokrasi. Partisipasi aktif warga negara dalam aktivitas politik merupakan salah satu ukuran dalam keefektifan proses demokratisasi. Salah satu ciri negara demokrasi adalah kedaulatan rakyat, artinya rakyatlah yang mempunyai kekuasaan yang tertinggi dan menentukan corak pemerintahan serta apa yang hendak dicapai. Sekolah melalui PKn diharapkan mampu mengembangkan dan meningkatan literasi dan partisipasi politik peserta didik. Materi kepemiluan merupakan bagian integral dari PKn. Selain itu juga terkait dengan tujuan PKn untuk membentuk warga negara yang cerdas, kritis dan partisipatif. Untuk itu diperlukan jalur pendidikan formal dengan cara-cara yang edukatif sebab pengetahuan, keterampilan dan perilaku warga negara yang demokratis tidak muncul secara alamiah tetapi harus diajarkan di bangku persekolahan kepada setiap generasi. Namun, dalam praktiknya, PKn seringkali diajarkan melalui metode konvensional yang cenderung monolog dan indoktrinatif. Pendidikan pemilih merupakan sumber pembelajaran PKn yang dapat meningkatkan partisipasi politik peserta didik melalui cara-cara yang inovatif dan kreatif. Dilakukan dengan perpaduan teori dan praktik sehingga belajar kepemiluan dan demokrasi menjadi menyenangkan.
\end{abstract}

Kata Kunci: Pendidikan Kewarganegaraan, Pendidikan Pemilih, Peserta didik 


\section{A. PENDAhuluan}

Indonesia merupakan negara demokrasi dengan jumlah penduduk terbesar keempat di dunia. dalam proses demokratisasi, indonesia memulai masa transisi demokrasi sejak tahun 1998, setelah tumbangnya orde baru di bawah kepemimpinan presiden soeharto selama lebih kurang 32 tahun. Sebelumnya, negara diperintah dengan cara-cara yang menjurus pada otoriterianismemiliteristik. Orde baru telah melaksanakan 6 kali masa pemilihan umum namun kualitas demokrasi berada pada tataran yang tidak memuaskan karena pemilihan umum dijadikan sebagai sarana legal yang dipolitisasi untuk mempertahankan status quo. Warga negara tidak mendapatkan hak informasi kepemiluan secara memadai serta tidak memiliki kebebasan dalam menentukan hak pilih. Warga negara telah diatur melalui segelintir peraturan dan kebijakan untuk memenangkan penguasa, diantaranya melalui kebijakan massa mengambang, praktik monoloyalitas PNS, fusi partai politik, hingga kebijakan pancasila sebagai ideologi tunggal. Partisipasi masyarakat ketika itu relatif tinggi yakni rata-rata diatas $90 \%$ dalam setiap pemilihan umum. Kualitas demokrasi dipertanyakan dan Pemilihan umum hanya dilihat sebagai sarana formal yang melegalkan kekuasaan elit. Gerakan reformasi 1998 merupakan bentuk luapan ketidakpuasan rakyat teradap praktik-praktik penyimpangan dalam proses demokrasi selama pemerintahan orde baru.

Namun, hal yang menarik pasca reformasi adalah tren penurunan tingkat partisipasi politik warga negara. Banyak faktor yang di tenggarai menjadi penyebab permasalahan ini diantaranya (1) kebebasan warga negara untuk mengekspresikan sikap politiknya terhadap kinerja pemerintahan tanpa takut dengan ancaman kekerasan seperti pada orde baru; (2) tidak ada lagi kebijakan yang memaksa warga negara untuk menentukan hak pilih-melalui propaganda dan peraturan yang menjurus pada satu organisasi politik tertentu--, yang ada hanyalah himbauan untuk memilih. Praktik semacam ini tentu tidak boleh dibiarkan karena kualitas pemilihan umum menentukan efektifitas proses demokratisasi. Warga negara harus didorong bahkan diberikan pembekalan agar memiliki literasi politik. Salah satu cara yang efektif dapat melalui sarana pendidikan pemilih. Hal ini dilakukan agar materi kepemiluan diberikan dengan cara-cara yang edukatif dan jauh dari unsur indoktrinatif. Sasaran pemilih yang urgen diberikan pendidikan pemilih adalah generasi muda yang masih duduk di bangku sekolah sebab peserta didik sebagai prapemilih dan/atau pemilih pemula seringkali digambarkan sebagai berikut (1) Pemilih yang masih labil dan cenderung apatis; (2) Pemilih yang memiliki pengetahuan politik yang relative rendah; (3) Pemilih yang cenderung didominasi oleh kelompok (peer group); (3) Pemilih yang melakukan pilihan karena aspek popularitas partai politik atau calon yang diusulkan partai politik; (4) Pemilih yang datang ke tempat pemungutan suara (TPS) hanya sekedar membatalkan atau menggugurkan haknya. Pendidikan pemilih penting dilakukan terhadap pemilih pemula mengingat pemilih pemula seringkali dinilai baru pada tahap penerimaan (akseptabilitas) dan belum sampai kepada pilihan politik (Nur Budi Hariyanto dalam Andi Faisal,2012:130). Jika pemilih pemula seperti peserta didik tidak memiliki pengetahuan dan pemahaman mengenai pemilihan umum maka mereka akan menjadi objek yang hanya diinginkan suaranya oleh peserta pemilihan umum. Pendidikan kewarganegaraan merupakan wahana bagi pelaksanaan pendidikan pemilih di sekolah. Pendidikan kewarganegaraan memberikan pengetahuan dan pemahaman kepada peserta didik untuk menjadi warga negara yang mengetahui hak dan kewajibannya. Menggunakan hak pilih dalam pemilihan umum merupakan hak setiap warga negara yang harus digunakan secara cerdas agar dapat menghasilkan pemilihan umum yang berkualitas dan pemimpin yang tepat. 
Pendidikan pemilih urgent diberikan kepada pemilih pemula karena ketiadaan pengalaman dan keterbatasan pengetahuan yang dimiliki sehingga mereka rentan untuk tidak menggunakan hak pilih dan memiliki kesadaran yang relatif rendah mengenai makna dan peranan strategis pemilihan umum di dalam negara Indonesia. Menurut Wakil Ketua MPR RI Hajrianto Thohari bahwa tren keikutsertaan pemilih pemula cenderung menurun dalam 3(tiga) pemilihan umum terakhir yakni Pemilu Legislatif Tahun 2004, Pemilu Legislatif Tahun 2009, serta Pemilu Presiden dan Wakil Presiden Tahun 2009. Kecenderungan ini membuktikan gagalnya pendidikan politik khususnya pendidikan pemilih. Tulisan ini bertujuan mendeskripsikan pendidikan pemilih sebagai sumber pembelajaran pendidikan kewarganegaraan (Pkn) untuk meningkatkan partisipasi politik peserta didik. metode yang digunakan adalah kajian literature melalui elaborasi sumber yang sesuai dengan tema kepenulisan baik dari rujukan buku maupun jurnal penelitian.

\section{B. PEMBAHASAN}

\section{Pendidikan Kewarganegaraan Dalam Peningkatan Literasi Politik Di Sekolah.}

Pendidikan politik merupakan sesuatu yang niscaya dalam sebuah negara demokrasi. Warga negara perlu mendapatkan pengetahuan dan pemahaman bahkan pencerahan seputar persoalan politik yang terjadi. Hal ini dilakukan agar warga negara tidak hanya menjadi objek dalam pengambilan keputusan politik melainkan dapat menjadi subjek yang memegang peranan penting dalam mempengaruhi pengambilan kebijakan karena pada hakikatnya dalam negara demokrasi, kedaulatan berada di tangan rakyat sehingga rakyat harus ikut serta atau berpartisipasi didalamnya. Untuk memunculkan partisipasi politik yang berkualitas diperlukan adanya pendidikan politik (Hariyanti:2015). Pengetahuan dan pemahaman politik yang jelas akan melahirkan kesadaran politik warga negara dalam menjalankan hak dan kewajibannya sebagai warga negara serta menuntunnya dalam bersikap dan menanggapi persoalan sosial politik di sekitarnya.

Pendidikan politik menurut Instruksi Presiden No.12 Tahun 1982 Tentang Pola Pembinaan dan Pengembangan Pendidikan Politik Generasi Muda, "pendidikan politik merupakan rangkaian usaha untuk meningkatkan dan memantapkan kesadaran politik dan kenegaraan untuk menunjang kelestarian pancasila dan UUD 1945 sebagai budaya politik bangsa. Pendidikan politik juga harus merupakan bagian proses perubahan kehidupan politik bangsa indonesia yang sedang dilakukan dewasa ini dalam rangka usaha menciptakan suatu system politik yang benar-benar demokratis, stabil, efektif dan efisien”. Pendidikan politik sebagai upaya meningkatkan pengetahuan politik warga negara dan agar mereka dapat berpartisipasi secara maksimal dalam system politiknya. Pendidikan politik diperuntukkan bagi warga negara untuk menambah wawasan kebangsaan dan kenegaraan yang melibatkan seluruh warga negara dan warga masyarakat. Jadi, dapat dikatakan bahwa pendidikan politik ditujukan pada upaya untuk meningkatkan pengetahuan, pemahaman serta kesadaran politik warga negara yang diharapkan berujung pada partisipasi aktif warga negara dalam proses politik. Aktivitas politik yang demikian menggambarkan warga negara telah memiliki literacy politic (melek politik) yang baik untuk membangun budaya politik yang partisipan (Rusadi kartaprawira 2004; Kennet P Langston,1969 dalam Sunatra:2016). Pendidikan politik lain dengan pendidikan dan pengajaran ilmu politik, walaupun dalam pengertian terakhir terkandung aspek-aspek pendidikan politik, tetapi tugas pokoknya adalah transferring konsep-konsep teoritis yang didukung oleh disiplin ilmunya. 
Ciri-ciri utama dalam pendidikan politik yaitu penekanan tidak pada konsep ilmu melainkan kepada daya manfaat riil yang pragmatis bagi manusia didiknya ke arah pembentukan pribadi-pribadi yang politically organized. Pendidikan politik tidak tidak memperuntukkan ahli ilmu politik. Pendidikan politik berupaya membentuk insan politik yang tanggap dan partisipatif terhadap kondisi masyarakat bangsanya. secara umum, pendidikan politik bertujuan untuk membentuk struktur politik yang mantap dalam masyarakat sebab kedua hal tersebut saling berkaitan. Individu yang memiliki literasi politik yang baik (melek politik) akan berupaya membangun masyarakat guna mewujudkan kesejahteraan dan ketertiban dalam masyarakat. Pendidikan memiliki ciri-ciri politis tertentu di antaranya, menuntun orang untuk memiliki sudut pandang, menilai benar salah, tuntutan normatif dan kerangka interpretatif. Pendidikan memilki peranan strategis dalam membentuk struktur pengetahuan kognitif, afektif dan psikomotor. Pendidikan yang terkait dengan pendidikan politik tidak hanya ditujukan agar warga negara melek politik dengan mengetahui konsep-konsep dan teori politik sebab yang dituju oleh pendidikan politik bukanlah membentuk para ahli ilmu politik tetapi membina warga negara sadar dan peduli terhadap peristiwa politik yang terjadi baik dalam konteks masyarakat maupun negara, diwujudkan dalam bentuk partisipasinya dalam proses politik tersebut. (A Kosasih Djahiri,1979 dalam sunatra:2016; Brownhill dan patricia smart, 1989; kartini kartono,2009). Terkait dengan beberapa pihak yang memiliki kewajiban yuridis maupun moral dalam melakukan pendidikan politik kepada warga negara diantaranya pemerintah, partai politik, lembaga swadaya masyarakat, keluarga, masyarakat dan sekolah.

Sekolah merupakan sarana pendidikan formal, melakukan proses pembelajaran dalam jenjang yang sistematis dan terstruktur. Melalui sarana pendidikan, pendidikan politik untuk meningkatkan literasi politik dapat dilakukan secara efektif, sasarannya adalah peserta didik sebagai warga negara muda dan generasi penerus bangsa yang akan mengambil peran dan pembangunan masyarakat dan negara sehingga mereka harus dibekali dengan pengetahuan politik kewarganegaraan. Selain itu, sekolah memiliki sarana dan prasarana yang mendukung diantaranya (1) fasilitas sekolah yang memudahkan peserta didik belajar teori dan praktik demokrasi dalam proses pembelajaran; (2) mata pelajaran pendidikan kewarganegaraan yang bertujuan meningkatkan literasi politik peserta didik. Namun, terdapat beberapa pendapat yang dengan keras menentang masuknya politik dalam praktik pendidikan. Anggapan ini dilatarbelakangi oleh asumsi bahwa pendidikan adalah sarana yang seharusnya membebaskan, harus terlepas dari kepentingan politik apapun. Pendapat ini misalnya disuarakan oleh ahli-ahli pendidikan seperti Paulo freire dan Michael apple. Keduanya dikenal sebagai tokoh pendidikan kritis yang menekankan pada kebebasan dunia pendidikan dari unsur politis dan bersifat indoktrinatif.

Dalam pemahaman penulis, kepentingan politik yang dimaksudkan disini adalah kepentingan politik penguasa yang diinfiltrasikan dalam perencanaann dan pelaksanaan kebijakan pendidikan yang menguntungkan satu kelompok. Kepentingan politik pragmatis ini ditujukan untuk memperluas kekuasaan dan mempertahankan status quo. Kepentingan politik yang dominan dalam pendidikan memang harus ditentang dengan beberapa alasan berikut (1) pendidikan adalah sarana untuk mencerdaskan warga negara bukan mengekang potensi dan kreatifitasnya, dengan kebijakan yang berorientasi pada kepentingan politik pragmatis penguasa; (2) sekolah merupakan labor demokrasi untuk membina dan meningkatkan pengetahuan politik peseta didik, bukan sarana indoktrinasi. Di sepanjang waktu kurikulum dan praktik pendidikan seluruhnya tdak dapat dibebaskan dari politik kekuasaan. Meskipun demikian, pembiaran sepenuhnya terhadap pendekatan kekuasaan dalam kurikulum dan 
pendidikan, entah mainstream entah alternatif terbukti menyebabkan proses dan mutu pendidikan hanya berayun-ayun seturut ayunan bandul kekuasaan.

Pendidikan dan politik merupakan dua hal yang terpisah sehingga sekolah sebagai basis pendidikan formal, guru sebagai pendidik dalam menerjemahkan pelaksanaan kurikulum dan kurikulum sebagai salah wadah dalam pencapaian tujuan pendidikan harus dipisahkan dari halhal yang berbau muatan politik. Namun, disisi lain, guru sebagai pelaksana kurikulum tidak lepas dari intervensi politik pemerintah dalam melaksanakan tugasnya, mereka diberikan arahan tentang apa yang harus dilakukan dan bagaimana mereka harus mengajarkannya. Sementara diketahui bahwa pemerintah merupakan gabungan dari koalisi partai politik dalam menjalankan kebijakannya walaupun orientasinya tidak selalu pragmatis tetapi jangka panjang untuk kemaslahatan warga negara. Namun, harus dikatakan bahwa pendidikan dan politik tidak dapat dipisahkan secara tegas, bahkan pendidik perlu memberikan pendidikan politik kepada siswa agar mereka memiliki literasi politik sebagai bekal dalam mengambil peran di tengah masyarakatnya dan menjadi warga negara yang baik, cerdas, kritis dan bertanggungjawab. Guru memiliki hak untuk memberikan pencerahan politik kepada siswa sebab sekolah merupakan labor demokrasi dalam negara demokratis.

Sebagai sarana pendidikan, sekolah memiliki peranan strategis dalam meningkatkan literasi politik peserta didik. Namun bukan berarti sekolah dapat dijadikan lahan bagi politisi untuk melaksanakan praktik-praktik politik praktis sebab berdasarkan peraturan perundanganundangan, sekolah merupakan tempat yang dilarang untuk melakukan kegiatan politik praktis diantaranya kampanye. Peranan disini dimaksudkan menanamkan dan meningkatkan pengetahuan, pemahaman dan keterampilan politik peserta didik sebagai bekal menjadi warga negara yang cerdas, kritis dan bertanggungjawab, terlepas peran dan karir yang akan digeluti setelah bangku persekolahan nantinya karena setiap warga negara memiliki hak, kewajiban dan tanggung jawab yang harus dipahaminya. Sekolah merupakan lembaga yang memiliki kewajiban akademis dan moral untuk mempersiapkan peserta didik menjadi pribadi dan warga negara yang cakap dan handal dalam berbagai bidang melalui sarana dan prasarana yang diberikan dalam proses pembelajaran dan pengalaman sekolah.

Dalam kepenulisan artikel ini, pendidikan politik dimaksudkan sebagai sarana pendidikan politik untuk meningkatkan literasi politik peserta didik di sekolah bukan ditujukan sebagai alat indoktrinasi untuk mendapatkan kepatuhan dari warga negara/peserta didik melainkan merujuk pada upaya edukatif yang intensional dan terarah yang bertujuan membangun literasi politik warga negara agar tercipta budaya politik yang partisipan. Pendidikan politik merupakan salah satu syarat efektifnya proses demokrasi. Oleh karena itu, pendidikan politik penting diberikan kepada warga negara. Salah satu pihak yang efektif dalam melakukannya adalah pendidik di sekolah utamanya dalam mata pelajaran pendidikan kewarganegaraan.

Pendidikan politik bermuatan konten yang mampu mendorong peserta didik untuk melaksanakan perannya sebagai warga masyarakat di lingkungannya, warga negara dalam konteks kehidupan bernegara hingga menjadi warga dunia. diantara konten tersebut adalah persoalan kewarganegaraan (meliputi hak, kewajiban dan tanggung jawab dalam berbagai bidang kehidupan sebagai warga negara) globalisasi, isu-isu kebangsaan, membangun sikap menjadi warga negara dan warga global yang baik, konsep dan praktik demokrasi, termasuk di dalamnya masalah-masalah kepemiluan yang menjadi salah satu tolak ukur suatu negara demokrasi. pengetahuan kepemiluan urgen dipahami oleh warga negara karena pemilihan umum merupakan sarana sirkulasi elit yang dilakukan secara demokratis dan konstitusional, diperlukan kecerdasan dalam menentukan hak pilih agar warga negara tidak salah pilih dalam menentukan pemimpin. 
Pengembangan iklim demokrasi dan membina jiwa demokratis peserta didik dalam lingkungan sekolah dilakukan melalui pendidikan kewarganegaraan (PKn) sebab konsep demokrasi dan kewarganegaraan merupakan substansi inti dari pendidikan kewarganegaraan. PKn ditujukan untuk membentuk warga negara yang baik dan cerdas, namun untuk membentuknya diperlukan jalur pendidikan formal dengan cara-cara yang edukatif seperti yang pernah diungkapkan Thomas Jefferson (dalam M.Fachri Adnan,Jurnal demokrasi Vol. IV No. 1/2005) bahwa "pengetahuan, keterampilan dan perilaku warga negara yang demokratis tidak muncul secara alamiah tetapi harus diajarkan di bangku persekolahan kepada setiap generasi”. Konsep demokrasi dan kewarganegaraan tidak boleh diajarkan hanya secara teoritis karena nilainilai demokrasi membutuhkan contoh tindakan praktis dan keteladanan. Konsep pembelajaran nilai demokrasi harus didukung oleh metode-metode yang menumbuhkan kesadaran dan pemahaman demokratis siswa melalui contoh-contoh nyata. Pernyataan ini didukung oleh hasil penelitian Fabio Aliverninia dan Sara Manganelli (2011) bahwa sekolah dengan nuansa kelas yang membuat ruang diskusi dan perbedaan pendapat dapat menjadi labor demokrasi untuk meningkatkan pengetahuan kewarganegaraan siswa. Pengetahuan kewarganegaraan penting dipahami siswa karena relasi sosial dalam masyarakat terdiri atas keberagaman biologis dan peran yang harus disadari dan dipahami agar tercipta suasana saling menghargai dan menghormati.

Penelitian tersebut dilakukan terhadap siswa-siswa sekolah di negara Italia. Namun, hasil dari penelitian tersebut dapat mendukung pernyataan sebelumnya bahwa sekolah merupakan labor demokarsi selama iklim sekolah mendukung proses demokratis tersebut dengan menjamin dan memfasilitasi keterbukaan diskusi dalam kelas, partisipasi siswa dan perbedaan pendapat sehingga pikiran dan jiwa mereka menjadi berkembang dan terlatih sebagai bekal dalam mengambil di lingkungannya masing-masing. Sekolah merupakan wadah bagi siswa untuk menjadi warga negara yang ideal. Ciri dari proses demokratis adalah keterbukaan dan kebebasan dalam mengemukakan pendapat, inilah yang harus difasilitasi oleh sekolah sebagai labor demokrasi dan guru pendidikan kewarganegaraan mempunyai peranan penting dalam mendorong hal tersebut.

\section{Pendidikan Pemilih Sebagai Sumber Pembelajaran Pendidikan Kewarganegaraan}

Pendidikan pemilih berisikan tentang pemahaman prosedur pemilihan untuk warga negara yang telah berhak memilih. Dari pendidikan ini diharapkan pemilih pemula berpartisipasi dengan mendatangi tempat pemungutan suara (TPS) untuk memilih (Nur Budi Hariyanto dalam Andi Faisal, 2012:144). Tidak hanya itu, mereka diharapkan ikut mengawasi jalannya pemilu, setidaknya penyelenggaraan yang harus sesuai dengan prosedur yang benar. Pendidikan pemilih tidak hanya menekankan pengetahuan seputar teknis pemberian suara namun lebih daripada itu yakni bagaimana pemilih dalam hal ini pemilih pemula dapat berpartisipasi aktif dalam jalannya pemilihan umum. Berpartisipasi aktif disini maksudnya mereka dapat memahami makna pemilihan umum di dalam negara demokrasi Indonesia serta mekanisme pemilihan umum tersebut sehingga dapat mengawasi jalannya pemilihan umum. Hal ini tentunya akan menciptakan pemilih yang cerdas dan pemilihan umum yang berkualitas.Pendidikan pemilih bertujuan meningkatkan pengetahuan dan pemahaman masyarakat tentang program, tahapan, jadwal, proses pemilihan umum dan makna serta pentingnya pemilihan umum di dalam negara demokrasi Indonesia. Selain itu, juga untuk meningkatkan kesadaran dan partisipasi pemilih dalam menggunakan hak pilihnya dalam pemilihan umum. Komisi Pemilihan Umum (KPU) 
dibantu dengan pihak terkait lainnya harus mampu memberikan kesan awal yang baik tentang pentingnya suara pemilih dalam pemilu, bahwa suara mereka dapat menentukan pemerintahan selanjutnya dan meningkatkan kesejahteraan hidup bangsa. Pemahaman yang baik itu diharapkan dapat menjadi motivasi untuk terus menjadi pemilih yang cerdas (KPU,2010: 48).

Pendidikan pemilih merupakan salah satu fungsi yang wajib dilakukan oleh KPU. Dalam melaksanakan fungsi tersebut, KPU dapat melakukan kerjasama dengan pihak lain untuk mendukung keefektifan pelaksanaan pendidikan pemilih. Salah satu pihak yang dapat diajak bekerjasama dalam kaitannya dengan sasaran peserta didik sebagai prapemilih dan pemilih pemula adalah pihak sekolah. Dalam hal ini, dilakukan melalui kerjasama dengan guru pendidkan kewarganegaraan. Hal ini dilakukan karena pertimbangan beberapa hal yakni (1) materi kepemiluan merupakan bagian integral dalam dari materi pendidikan kewarganegaraan; (2) pendidikan kewarganegaraa bertujuan untuk membina peserta didik menjadi warga negara yang baik, cerdas, kritis dan bertanggung jawab. Ciri dari warga negara yang baik adalah warga negara yang mengetahui hak, kewajiban dan tanggung jawabnya sebagai warga negara. Mendapatkan informasi kepemiluan dan Melaksanakan hak pilih dalam pemilu secara berkualita ---tidak sekedar menggugurkan hak pilih-merupakan hak yang wajib diketahui oleh setiap warga negara tidak terkecuali peserta didik sebagai prapemilih dan pemilih pemula.

Menurut Marratu Fahri (dalam Jurnal Online FISIP UNBARA Volume 1, Nomor 2, Desember 2008) Pendidikan pemilih dapat menjadi metode preventif yang efektif untuk mengeliminasi konflik massa dalam proses pemilu. Oleh karena itu, sikap saling menghormati, toleran dan menghargai hak pilih orang lain harus dibangun dan diinternalisasikan dalam diri setiap individu calon pemilih. Kalah dan menang dalam pemilu adalah sesuatu yang wajar dan biasa. Dan itu harus menjadi kesadaran bersama masyarakat. Oleh karena itu, pendidikan pemilih merupakan tanggungjawab bersama seluruh komponen bangsa, karena pemilu merupakan salah satu sarana strategis untuk membangun masa depan bangsa yang lebih baik. Beban tanggungjawab tersebut hendaknya dipikul bersama-sama, salah satunya oleh KPU sebagaimana diamanatkan undang-undang.

Pendidikan kewarganegaraan merupakan wahana bagi pelaksanaan pendidikan pemilih di sekolah. Pendidikan kewarganegaraan memberikan pengetahuan dan pemahaman kepada peserta didik untuk menjadi warga negara yang mengetahui hak dan kewajibannya. Menggunakan hak pilih dalam pemilihan umum merupakan hak setiap warga negara yang harus digunakan secara cerdas agar dapat menghasilkan pemilihan umum yang berkualitas dan pemimpin yang tepat. Pendidikan pemilih penting dilakukan terhadap pemilih pemula mengingat pemilih pemula seringkali dinilai baru pada tahap penerimaan (akseptabilitas) dan belum sampai kepada pilihan politik (Nur Budi Hariyanto dalam Andi Faisal,2012:130). Jika pemilih pemula seperti peserta didik tidak memiliki pengetahuan dan pemahaman mengenai pemilihan umum maka mereka akan menjadi objek yang hanya diinginkan suaranya oleh peserta pemilihan umum. Pendidikan pemilih untuk pemilih pemula seperti yang dilakukan oleh partai politik cenderung lebih mengarahkan mereka untuk memihak pada partai tertentu tanpa diberikan pencerahan secara jernih mengenai makna dan pentingnya pemilihan umum. Pendidikan pemilih merupakan sebuah proses yang memiliki peranan strategis terhadap pelaksanaan pemilihan umum. Proses ini bukan hanya sekedar memberikan pemahaman tentang teknik dan tata cara pencoblosan dan halhal yang bersifat teknis lainnya, melainkan dapat menyentuh pada nilai yang lebih mengarah pada arti dan peran penting pemilihan umum terhadap masyarakat. Diharapkan akan terjadi suatu perubahan pola pikir masyarakat yang tidak hanya menganggap pemilihan umum sebagai sebuah 
rutinitas pemilihan sekali lima tahunan. Dalam tatanan masyarakat, pemilih cerdas memiliki posisi dan peranan yang sangat stategis untuk menciptakan demokratisasi. Iklim demokratisasi yang dibangun pada era reformasi ini, harusnya menjadi momen dimana pemilih cerdas tampil sebagai pengawal proses tersebut (www.JPRR.com, 5 Desember 2012).

Pendidikan pemilih telah dilakukan oleh pihak penyelenggara pemilihan umum (KPU) melalui kerjasama dengan berbagai pihak termasuk sekolah dengan melakukan komunikasi intens dengan guru pendidikan kewarganegaraan. Hal ini dilakukan mengingat keterkaitan tujuan dan keintegralan materi PKn dengan persoalan kepemiluan. Sejauh ini terdapat beberapa program pendidikan pemilih sebagai sumber pelajaran PKn di sekolah diantaranya: pertama, sosialisasi kepemiluan menjelang gelaran pemilu ke sekolah-sekolah oleh komisi pemilihan umum. Kegiatan ini bertujuan untuk mengedukasi peserta didik terntang persoalan kepemiluan, dilakukan melalui pemaparan materi kepemiluan, diselingi dengan diskusi dan Tanya jawab serta umumnya diakhiri dengan pemutaran video tentang tata cara dalam memberikan suara di tempat pemungutan suara. Metode semacam ini perlu dilakukan mengingat peserta didik sebagai prapemilih maupun pemilih pemula memiliki keterbatasan pengetahuan sehingga kurang memahami alur proses demokrasi langsung tersebut, hal inilah yang rentan menyebabkan mereka menjadi objek kepentingan politik pragmatis segelintir elit politik yang tidak bertanggung jawab, yang hanya ingin memobilisasi suara mereka tanpa memberikan edukasi politik. Peserta didik sebagai prapemilih dan/atau pemilih pemula seringkali digambarkan sebagai berikut (1) Pemilih yang masih labil dan cenderung apatis; (2) Pemilih yang memiliki pengetahuan politik yang relative rendah; (3) Pemilih yang cenderung didominasi oleh kelompok (peer group); (3) Pemilih yang melakukan pilihan karena aspek popularitas partai politik atau calon yang diusulkan partai politik; (4) Pemilih yang datang ke tempat pemungutan suara (TPS) hanya sekedar membatalkan atau menggugurkan haknya. Pendidikan pemilih penting dilakukan terhadap pemilih pemula mengingat pemilih pemula seringkali dinilai baru pada tahap penerimaan (akseptabilitas) dan belum sampai kepada pilihan politik (Nur Budi Hariyanto dalam Andi Faisal,2012:130). Jika hal ini dibiarkan berlarut dan berlanjut akan tercipta apatisme politik bahkan cenderung akan membentuk persepsi dan sikap apolitik di kemudian hari, hal ini tentu berbahaya bagi keberlanjutan proses berdemokrasi di indonesia yang bertumpu pada partisipasi politik warga negara. Namun, kegiatan sosialisasi ini setidaknya dapat dikatakan mengandung beberapa kelemahan diantaranya (1) hanya dilakukan menjelang gelaran pemilihan umum sehingga sifatnya tidak berkelanjutan dan berkesinambungan; (2) kegiatan sosialisasi kepemiluan cenderung hanya dilakukan di beberapa sekolah tertentu sehingga kejelasan informasi kepemiluan dari sumber yang valid seperti KPU tidak didapatkan semua peserta didik; (3) kegiatan sosialisasi yang tidak dilakukan secara berkala cenderung akan membentuk persepsi diantara peserta didik bahwa informasi kepemiluan hanya diperlukan menjelang gelaran kepemiluan, hal ini tentu menyimpang dari tujuan pendidikan pemilih yang ditujukan untuk meningkatkan partisipasi politik peserta didik, tidak hanya partisipasi langsung melalui pemberian suara di TPS tetapi juga dalam bentuk kegiatan partisipasi politik dalam konteks kemasyarakatan lainnya sebab dalam pendidikan pemilih, tidak hanya diberikan edukasi kepemiluan tetapi juga mencakup mengenai lingkup hak, kewajiban dan tanggung jawab warga negara dalam negara demokrasi Indonesia.

Bentuk pendidikan pemilih dengan orientasi peserta didik kedua adalah program relawan demokrasi, terdiri dari beberapa segmen pemilih yang telah ditentukan KPU diantaranya kelompok perempuan, kaum marginal, penyandang disabilitas, kelompok agama, serta pemilih pemula. Salah satu lokasi edukasi untuk pemilih pemula yang disasar oleh relawan 
demokrasi adalah sekolah. Peserta didik masuk kepada kategori pemilih pemula bagi yang telah memenuhi syarat sesuai dengan UU pemilu maupun prapemilih yang membutuhkan informasi kepemiluan dan demokrasi sebagai bekal untuk menunaikan hak dan kewajibannya sebagai warga negara, tidak hanya partisipasi politik dalam pemilu. Program relawan demokrasi digulirkan menjelang pemilihan umum legislatif 2014 lalu, khusus bagi sasaran pemilih pemula, dilakukan di beberapa sekolah di wilayah tertentu sesuai dengan pembagian yang telah ditetapkan oleh relawan demokrasi segmen pemilih pemula. Relawan demokrasi direkrut oleh KPU dari masyarakat yang peduli dan berkeinginan untuk berpartisipasi dalam proses demokrasi melalui penyebaran informasi dan mengedukasi kelompok masyarakat di sekitarnya sesuai dengan segmen-segmen pemilih yang telah ditetapkan oleh KPU. Namun, terkait dengan kelemahan program ini bagi pemilih khususnya bagi peserta didik sebagai pemilih pemula/prapemilih adalah sama dengan kegiatan sosialisasi kepemiluan yakni program relawan demokrasi sifatnya tidak berkesinamabungan.

Kegiatan pendidikan pemilih ketiga adalah kelas pemilu, merupakan bagian dari Pendidikan pemilih yang dilakukan oleh KPU Kab/Kota sebagaimana yang diatur dalam Undang-Undang No.15 Tahun 2011 Tentang Penyelenggara Pemilu. Penjabaran lebih lanjut mengenai kewajiban KPU Kabupaten/Kota dalam penyelenggaraan sosialisasi pemilihan umum kepala daerah dan wakil kepala daerah diatur dalam Peraturan Komisi Pemilihan Umum (PKPU) No.11 Tahun 2010 Tentang Sosialisasi Pemilihan Umum Kepala Daerah dan Wakil Kepala Daerah. Pendidikan Pemilih/Voters Education bukanlah program yang hanya dapat dilakukan menjelang digelarnya hajat Pemilihan Umum tetapi lebih kepada pola kegiatan yang berkesinambungan dari waktu ke waktu. Sasaran dari kegiatan kelas pemilu adalah pemilih pemula yang masih duduk di bangku sekolah menengah.

Pemilih pemula merupakan salah satu dari 11 (sebelas) kelompok sasaran dalam pelaksanaan sosialisasi dan penyampaian informasi Pemilu sebagaimana yang diatur dalam pasal 7 ayat (1) PKPU No.10 Tahun 2011 Tentang Pedoman Pelaksanaan Sosialisasi Penyelenggaraan Pemilihan Kepala Daerah dan wakil Kepala Daerah. Salah satu KPU daerah yang melakukan kegiatan tersebut adalah KPU Kota Padang pada 2013 menjelang pemilihan umum walikota dan wakil walikota padang tahun 2013. Kerjasama dengan berbagai pihak yang dilakukan oleh KPU Kota Padang khususnya dengan MGMP PKn dilakukan mengingat terciptanya pemilih yang cerdas dan pemilihan umum yang berkualitas bukanlah sekedar tanggung jawab penyelenggara pemilu semata tetapi semua elemen bangsa. Pendidikan pemilih berbentuk kelas pemilu yang dilaksanakan oleh KPU Kota Padang dilakukan dengan berpedoman kepada modul kelas pemilu yang telah disusun sebelumnya. Kegiatan kelas pemilu menggunakan metode BRIDGE (Building Resources in Democracy, Government and Election)". Metode BRIDGE membantu peserta didik memahami tahapan pemililihan umum melalui indera yang dimiliki. Peserta didik mendengar materi yang diberikan, melihat contoh nyata yang ditayangkan melalui slide-slide materi dan gambar oleh pemateri, mempraktekkan materi-materi yang diberikan melalui bahan dan peralatan yang digunakan dalam proses pemilihan umum secara langsung seperti kotak suara, bilik suara, surat suara, hingga terlibat langsung sebagai pelaksana pemilihan umum. Ini merupakan hal yang baru bagi peserta didik karena mereka belum memiliki pengalaman sebelumnya dalam proses pemilihan umum. Pelaksanaan kegiatan kelas pemilu oleh KPU daerah umunya bekerjasama dengan MGMP PKn SMA/MA/SMK. Namun, dalam pelaksanaanya juga tidak terlepas dari kendala-kendala yang berasal dari internal maupun eksternal, diantaranya (a) Waktu pelaksanaan kelas pemilu yang terlalu sempit. Alokasi waktu yang ditetapkan dalam modul kelas pemilu adalah sekitar 120 menit namun dalam pelaksanaannya hanya dilaksanakan 
selama 90 menit. Masalah waktu pelaksanaan ini menjadi kendala karena untuk menyampaikan materi pemilihan umum yang lumayan banyak dan lebih mendalam seperti yang telah disusun dalam modul kelas pemilu; (b) modul kelas pemilu yang tidak bisa dilaksanakan di sekolahsekolah yang tidak menjadi sekolah sasaran kelas pemilu yang dilaksanakan KPU (Hariyanti:2017).

Keempat, Saat ini, sebagai bentuk pendidikan pemilih berkelanjutan, KPU merancang sebuah program dengan membangun sebuah pusat pendidikan pemilih di daerah-daerah yang dikelola oleh KPU daerah dan pusat yakni rumah pintar pemilu/rumah demokrasi. Pada Tahun 2015 lalu, KPU menjalankan program pilot project pendidikan pemilih di 18 KPU provinsi dan KPU kabupaten/kota di Indonesia. KPU merancang semacam rumah demokrasi atau zona cerdas pemilu di masing-masing kantor KPU daerah yang menjadi percontohan, masyarakat dapat mendatangi rumah demokrasi tersebut untuk mengetahui informasi kepemiluan secara lebih lengkap dan jelas. Tentu hal ini harus kita apresiasi sebagai bentuk komitmen dan keseriusan KPU dalam menyelenggarakan pendidikan pemilih namun di satu pihak hal ini tentu membutuhkan biaya jika guru PPKn membawa peserta didik mengunjungi rumah demokrasi di kantor KPU daerahnya guna mendapatkan informasi kepemiluan yang komprehensif. Selain juga dibutuhkan waktu yang khusus untuk membawa peserta didik ke rumah demokrasi mengingat tidak mungkin memakai jam pelajaran pendidikan pancasila dan kewarganegaraan atau jam mata pelajaran jika ingin belajar kepemiluan di KPU. Kemudian, juga tidak memungkinkan membawa banyak peserta didik ke rumah demokrasi karena keterbatasan ruangan. Inilah kira-kira kelemahan yang coba carikan solusi bersama demi perbaikan kualitas demokrasi melalui pencerdasan pemilih khususnya pemilih pemula.

Berdasarkan pemaparan bentuk-bentuk pendidikan pemilih diatas, guna keefektifan dalam pelaksanaannya sebagai sumber pembelajaran pendidikan kewarganegaraan di sekolah guna meningkatkan partisipasi politik peserta didik sebagai prapemilih/pemilih pemula maupun sebagai warga negara dalam memahami dan menjalankan hak, kewajiban dan kewajiban dalam kehidupan bermasyarakat dan bernegara, maka diperlukan sebuah pegangan atau pedoman dalam mempelajari persoalan kepemiluan dan demokrasi di sekolah. Hal ini tidak berarti bahwa materi pendidikan kewarganegaraan tidak cukup efektif dalam membentuk peserta didik menjadi warga negara yang baik dan cerdasm hanya saja dibutuhkan suatu buku pegangan khusus seputar kepemiluan dan demokrasi disertai dengan strategi kerjasama dengan KPU melalui kunjungan ke rumah demokrasi. kegiatan ini ditujukan untuk meningkatkan pengetahuan, pemahaman dan keterampiran/partisipasi politik peserta didik. Guru pendidikan kewarganegaraan memiliki keterbatasan pengetahuan yang mendetail seputar kepemiluan karena pendidikan kewarganegaraan merupakan bidang kajian yang multifacet (Abdul Aziz Wahab dan Sapriya:2011) sehingga bidang kajian yang harus dikuasasi oleh guru beragam sifatnya mulai dari hukum, politik, dan pendidikan. Kesemuanya diberikan agar peserta didik mengetahui dan memahami persoalan politik kewarganegaraan melalui pembelajaran di sekolah sebagai bekal guna mengambil peran di masyarakat sebab sekolah mempunyai peranan untuk itu, sebagaimana yang dinyatakan oleh Fabio Aliverninia dan Sara Manganellia 2011). Dalam penelitiannya, mereka menyatakan bahwa keterbukaan dalam pembelajaran PKn utamanya dalam diskusi kelas yang terbuka dapat mempengaruhi pengetahuan kewarganegaraan (siswa). Mereka menguji dengan menggunakan model regresi bertingkat dengan dua tingkat/level diuji berdasarkan skala skor ICSS untuk pengetahuan kewarganegaraan sebagai variabel dependen dan persepsi siswa tentang keterbukaan dalam diskusi kelas sebagai variabel independen di tingkat sekolah. Berbagai variabel kontrol dianalisis. Hasil skor pengetahuan kewarganegaraan siswa secara 
signifikan lebih tinggi jika di sekolahnya ada iklim kelas yang terbuka untuk diskusi. The international civic and citizenship studi menyelidiki peranan sekolah dalam mempersiapkan peserta didik untuk berperan sebagai warga negara.

Buku saku atau modul kepemiluan merupakan media yang cocok digunakan dalam penyampaian informasi kepemiluan kepada peserta didik. Buku saku tersebut dirancang dengan muatan materi sebagai berikut pengertian pemilu, sejarah pemilu di Indonesia, jenis-jenis pemilu di Indonesia, penyelenggara pemilu, peserta pemilu, dasar hukum penyelenggaraan pemilu, system pemilu di Indonesia, tahapan pemilu, proses dan makna serta arti pentingnya pelaksanaan pemilu dalam negara demokrasi, kiat-kiat menjadi pemilih cerdas, peranan pemilih dalam pengawasan terhadap proses pemilu yang demokratis, proses penyelesaian masalah hukum kepemiluan serta praktik-praktik pemilu di beberapa negara. Buku saku tersebut dirancang dengan model yang menarik dan disertai dengan gambar-gambar kepemiluan yang berwarna dan komunikatif sehingga materi kepemiluan yang termuat di dalamnya dapat dengan mudah dicerna oleh peserta didik. Sebelumnya, kerjasama MGMP PKN dengan komisi pemilihan umum terkait dengan pembuatan panduan kepemiluan berbentuk modul kelas pemilu untuk pemilih pemula telah pernah dilakukan pada sekitar 2012 lalu. Untuk mengantisipasi efisiensi dalam penyampaian materi kepemiluan agar tidak menyita waktu peserta didik terlalu banyak, maka perlu dilakukan pengintegrasian materi-materi kepemiluan dalam Perangkat Pembelajaran PKn yakni RPP melalui materi-materi PKn yang terkait dengan pemilu seperti budaya politik dan sistem pemerintahan. Hal ini diserahkan pada kebijaksanaan dan rasa tanggung jawab guru dalam membentuk peserta didik menjadi pemilih yang cerdas dan rasional guna mewujudkan warga negara yang aktif dan partisipatif. MGMP PKn memegang peranan penting dalam mengarahkan guru-guru pendidikan kewarganegaraan dalam pengintegrasian materi kepemiluan dalam RPP melalui diskusi bersama terkait dengan materi kepemiluan yang dapat diintegrasikan kedalam Komptensi Dasar (KD) tertentu. Hal ini dilakukan agar pendidikan pemilih dapat dilakukan secara berkelanjutan, tidak membutuhkan waktu atau jadwal khusus yang dapat menambah beban belajar peserta didik. Langkah ini didukung dengan adanya buku saku kepemiluan yang dibuat bersama oleh KPU dan MGMP PKn sehingga peserta didik memiliki bahan yang akan didiskusikan dalam setiap pertemuan serta memungkinkan guru pendidikan kewarganegaraan memantau pemahaman peserta didik terkait materi kepemiluan.

Selain itu, efektifitas pelaksanaan pendidikan pemilih berkelanjutan sebagai sumber pembelajaran pendidikan kewarganegaraan dapat ditunjang dengan kegiatan kunjungan ke rumah demokrasi/rumah pintar pemilu yang dibangun dan dikelola oleh KPU daerah. Saat ini, belum semua KPU daerah memiliki rumah pintar pemilu, diharapkan ke depannya masingmasing KPU daerah apakah itu di KPU kabupaten atau kota mempunyai rumah pintar pemilu sebagai sarana pembelajaran kepemiluan untuk menunjang serta meningkatkan partisipasi politik masyarakat utamanya peserta didik sebagai prapemilih/pemilih pemula.

\section{PENUTUP}

Pendidikan pemilih urgent diberikan kepada pemilih pemula karena ketiadaan pengalaman dan keterbatasan pengetahuan yang dimiliki sehingga mereka rentan untuk tidak menggunakan hak pilih dan memiliki kesadaran yang relatif rendah mengenai makna dan peranan strategis pemilihan umum di dalam negara Indonesia. jika dibiarkan berlarut dan berlanjut, kondisi akan mengancam proses demokratisasi yang telah diperjuangkan bangsa indonesia. Pengembangan iklim demokrasi dan membina jiwa demokratis peserta dalam lingkungan sekolah dilakukan melalui pendidikan kewarganegaraan (PKn) sebab konsep 
demokrasi dan kewarganegaraan merupakan substansi inti dari pendidikan kewarganegaraan. PKn ditujukan untuk membentuk warga negara yang baik dan cerdas, namun untuk membentuknya diperlukan jalur pendidikan formal dengan cara-cara yang edukatif. Konsep pembelajaran nilai demokrasi harus didukung oleh metode-metode yang menumbuhkan kesadaran dan pemahaman demokratis siswa melalui contoh-contoh nyata. pendidikan kewarganegaraan merupakan bagian dari Pendidikan pemilih di sekolah. Guru PKn memiliki tanggung jawab akademik dan moral untuk membina peserta didik menjadi warga negara yang baik, cerdas, kritis, dan partisipatif. Materi kepemiluan merupakan bagian integral dari pendidikan kewarganegaraan sehingga pendidikan pemilih dapat menjadi sumber pembelajaran PKn untuk menunjang dan meningkatkan pengetahuan, pemahaman dan keterampilan politik peserta didik, tidak hanya pada konteks hak dan kewajiban dalam pemilihan umum tetapi dalam lingkup peran sebagai warga negara. Pendidikan pemilih yang telah dilaksanakan selama ini oleh penyelenggara pemilu kerjasama dengan Guru PKn dan pihak sekolah dengan sasaran para peserta didik adalah (1) sosialisasi pemilhan umum; (2) program relawan demokrasi; (3) kegiatan kelas pemilu; (4) rumah pintar pemilu/rumah demokrasi. Untuk keefektifan pelaksanaan, meminimalisasi kelemahan dan menciptakan pendidikan pemilih yang berkelanjutan, disarankan agar kedepannya, dibuat sebuah buku saku/modul kepemiluan yang dapat diintegrasikan ke dalam mata pelajaran PKn di sekolah serta ditunjang dengan kegiatan kunjungan ke rumah pintar pemilu/rumah demokrasi yang dikelola oleh KPU daerah. Oleh karena itu, jug disarankan agar di setiap KPU daerah baik provinsi/kabupaten/kota diadakan sebuah rumah pintar pemilu/rumah demokrasi sebagai sarana pembelajaran kepemiluan bagi peserta didik melalui pembinaan dari KPU dan guru PKn.

\section{Daftar Pustaka}

Abdul Aziz Wahab dan Sapriya. 2011. Teori dan Landasan Pendidikan Kewarganegaraan. Bandung: Alfabeta.

Andi Faisal Bakti, dkk.,Eds. 2012. Literasi Politik dan Konsolidasi Demokrasi. Churia:Jakarta. Brownhill dan Patricia Smart. 1989. Political Education.

Fabio Aliverninia Dan Sara Manganelli.(2011) Is There A Relationship Between Openness In Classroom Discussion And Students' Knowledge In Civic And Citizenship Education?. Procedia - Social And Behavioral Sciences.Vol 15 Page 3441-3445.

Hariyanti. 2015. Pelaksanaan pendidikan pemilih melalui kerjasama KPU Kota Padang dengan MGMP PKn SMA/MA/SMK Kota Padang. Skripsi

.2017. Class Election: The Cope of Constraints Towards Voter Education Sustainability. Proceeding internasional conference on education and research innovation. Lembaga penelitian dan pengabdian masyarakat Universitas negeri Yogyakarta, 8-9 Mei 2017.

Instruksi Presiden No.12 Tahun 1982 Tentang Pola Pembinaan dan Pengembangan Pendidikan Politik Generasi Muda.

Komisi Pemilihan Umum. 2010. Modul 1: pemilu untuk pemula, cet. Pertama. Komisi Pemilihan Umum: Jakarta.

Kartini Kartono. 2010. Pendidikan Politik. Bandung: Mandar Maju.

Komisi Pemilihan Umum Kota Padang. 2012. Modul Kelas Pemilu. 
Marratu Fahri. 2008. "Peranan Penyelenggara Pemilu Dalam Pendidikan Pemilih Untuk Mewujudkan Pemilu Yang Berkualitas." Jurnal Dinamika Online FISIP Universitas Batubara. (Volume 1, Nomor 2, Desember 2008). Hlm. 4-6.

M.Fachri Adnan, Pendidikan Kewarganegaraan Dalam Era Demokratisasi ( Jurnal demokrasi Vo. IV No.1/2005).

PKPU No.10 Tahun 2011 Tentang Pedoman Pelaksanaan Sosialisasi Penyelenggaraan Pemilihan Kepala Daerah dan wakil Kepala Daerah

Suara KPU Edisi Juni 2011

Sunatra. 2016. Pendidikan politik kewarganegaraan. Bandung: Lekkas

Undang-Undang No.15 Tahun 2011 Tentang Penyelenggara Pemilihan Umum

http://.www.JPPR.com (diakses pada 22 September 2014)

http://.www.JurnalParlemen.com (diakses pada 22 September 2014) 